\title{
Refining material transport in the mantle wedge of the northernmost Tonga island arc
}

\author{
BETTINA STORCH ${ }^{1}$, MARCEL REGELOUS ${ }^{2}$, KRISTINA \\ NOEBEL $^{1,3}$, JULIA BAUER ${ }^{1}$ AND KARSTEN M. HAASE ${ }^{2}$ \\ ${ }^{1}$ GeoZentrum Nordbayern, Friedrich-Alexander-Universität \\ (FAU) Erlangen-Nürnberg, Germany \\ ${ }^{2}$ GeoZentrum Nordbayern, Friedrich-Alexander-Universität \\ (FAU) Erlangen-Nürnberg \\ ${ }^{3}$ ETH Zurich, Institut for Geochemistry and Petrology \\ Presenting Author: bettina.storch@fau.de
}

Volcanic islands of the northernmost Tonga Island Arc erupt lavas with isotopic and incompatible element compositions that imply variable input of pelagic sediments and material from the subducting Louisville Seamount Chain (LSC) into the mantle wedge. We provide new geochemical and isotope compositions of lavas from six young submarine volcanoes of the northernmost Tonga Arc. Northern Tonga arc lavas have highly variable trace element and $\mathrm{Sr}, \mathrm{Nd}, \mathrm{Hf}$ and $\mathrm{Pb}$ isotope compositions, which extend to higher ${ }^{87} \mathrm{Sr} /{ }^{86} \mathrm{Sr}$ and ${ }^{208} \mathrm{~Pb} /{ }^{206} \mathrm{~Pb}$, lower ${ }^{143} \mathrm{Nd} /{ }^{144} \mathrm{Nd}$ and ${ }^{176} \mathrm{Hf} /{ }^{177} \mathrm{Hf}$, and higher $\mathrm{Nb} / \mathrm{Zr}$ and $\mathrm{La} / \mathrm{Sm}$ than all other Tonga-Kermadec lavas. The observed variations in the seamount lavas suggest mixing between a slab-derived hydrous fluid and a partial melt of OIB mantle. The fluid component probably formed from a subducted mixture of pelagic and LSC volcaniclastic sediments. The partial melt is enriched in $\mathrm{Nb}$ and other fluid-immobile elements and resembles posterosional lava compositions from rejuvenated lavas from Savai'i of the Samoa hotspot. Our data implies, that the mantle heterogeneity causing the post-erosional magmas at Samoa also occurs beneath the northernmost Tonga arc. The Louisville $\mathrm{Pb}$ component is only found in lavas from volcanoes spanning $<50$ $\mathrm{km}$ of the arc front, indicating that the oceanic crust loses $\mathrm{Pb}$ by dehydration over a relatively small depth interval during subduction. 